\title{
SOCIAL COMPETENCIES AND PERSPECTIVES OF HUMAN RESOURCES IN LOGISTICS ORGANIZATION
}

\author{
Ramūnas Palšaitis ${ }^{1}$, Kristina Čižiūniené2 ${ }^{2}$ Kristina Vaičiūtè $\dot{3}^{3}$ \\ 1, 2 Department of Logistics and Transport Management Vilnius Gediminas Technical University, \\ Plytinès g. 27, LT-10105 Vilnius, Lithuania \\ ${ }^{3}$ Department of Social Economics and Management, Vilnius Gediminas Technical University, \\ Sauletekio al. 11, LT-10223 Vilnius, Lithuania \\ E-mails: ${ }^{1}$ ramunas.palsaitis@vgtu.lt; ${ }^{2}$ kristina.ciziuniene@vgtu.lt; \\ ${ }^{3}$ kristina.vaiciute@vgtu.lt (corresponding author)
}

\begin{abstract}
Clients of logistics organizations often demand not only one service, but a total logistics package. Therefore, globalization of economic, social and cultural processes pose new challenges for human resource management. The paper analyzes the impact of human resource competence features and its use as a tool for development of logistics organization and logistics service quality assurance. Competence measurement is complicated, it requires sophisticated studies, thus competence is often assessed on the grounds of simple, easily expressed, but often frustrated total image indicators, such as education and training. The conducted qualitative research enabled the identification of human resource social competence problematics in logistics organizations.
\end{abstract}

Keywords: human resources, human resources of logistics organization, competencies, social competence, management, warehousing, logistics.

JEL Classification: J240; J530; J540; M540.

\section{Introduction}

Human resources create value for organization when they are used and efficiently managed in conjunction with other resources, which emphasizes the importance of human resource management system. Production process innovation, productivity and quality directly depend on employee competence and qualification.

The novelty of the topic. With reference to the scientific literature, the article presents the effect of human resource competence peculiarities and its use as a tool for development of logistics organization and logistics service quality assurance. Management of human resource competencies is presented as the research problem analysis by defining concepts of human resources, relevance and essence from the perspective of theoretical modelling and methodological aspects.

The object of the Article - competencies of human resources in logistics organizations.

The aim of the Article - to investigate the effect of human resource competence peculiarities and its use as a tool for development of logistics organization and logistics service quality assurance.

The objectives of the Article: 1) To analyse the role of human resource competencies in logistics organization; 2) To analyse and distinguish the relevance of employee competence in logistics organizations; 3) To carry-out an expert assessment of logistics organizations: research on human resource competencies in logistics organizations.

The Methodology of the Article: Research analysis of Scientific Literature, Collection of Statistical Data and Grouping, Synthesis, Qualitative Research.

\section{Organization performance management from the perspective of human resource management}

Configuration and empowerment is a creative and entrepreneurial process for organization in pursuance of financial gain Priem and Cycyota (2001) claim that resource empowerment process requires specific tacit knowledge that is usually embedded in human capital. Thus, efficient resource empowerment process requires substantial managerial experience as a primary source of tacit knowledge. Unique organizational competence is a combination of resources that affect organization's ability to develop resources and create competitive advantage, (Fitzroy, Hulbert 2005). So Human resource management is one of the most important processes in each organization (Čižiūnienè et al. 2015). 
Proper formulation of the righteous human resource management policy will help to obtain the following objectives:

- Bringing together personnel into cohesive unit effectively participating in implementation of organization's mission and goals;

- Create a modern employee incentive system enabling each team member to achieve better results and motivating to work in a qualified and creative manner;

- Develop an efficient competence and knowledge management system facilitating employee improvement not only in terms of their profession, but also in mastering neccessary, modern competencies.

Human resources create value for organization when they are used and efficiently managed in conjunction with other resources. Underis (2015) claims, that human resource management policy is often equated with human resources management strategy and human resource policy is defined as a document, which describes in detail the long-term organizational values, aspirations and expectations for individual employees, principles of conduct within organization (Underis 2015). According to Leonienè (2001), human resource management policy provides no specific means to solve certain organizational tasks, however, solution principles are distinguished, managers and co-workers behavioral rules are established on the basis of humanism and responsibility towards the society ideals. According to the author, a great emphasis in human resource management policy is placed on the following points:

- operational safety and social welfare;

- establishment of good relationships between different groups of employees;

- owners' commitment to improve human potential in an organization;

- Fair pay for work;

- Motivation of Employee Performance Results.

A creative indvidual is constantly reflecting on his future activities. Creativity is mainly linked to innovations. On the other hand, to create means to make up individual decisions. Decisions tend to be made by confident, creative individuals.

Global economical, social and cultural processes pose new challanges for management of human resources. Logistics sector in Lithuania is one of the key branches of Economics that is stable and yet constantly developed (Čižiūnienè, Štaraite 2015; Čižiūnienè et al. 2015; Prentkovskis et al. 2009). Considering this, requirements for the competencies of logistics sector specialists will in- crease qualitatively (Barysienè et al. 2015). According Ledauskaite and Bazaras (2008) it is necessary to educate specialists with wide spectrum of competencies.

\section{Modeling of social competence}

Competence - a cluster of related abilities, knowledge and skills that enable a person to act effectively (Lietuvos Respublikos Seimas 2004).

The most united and clearly understood element of competence is knowledge. According to Becker (2008), Armstrong (1999) and Stukaite (2000), it is possible to distinguish the following types of competencies:

- Professional (specialty) competence, comprising all the knowledge, training required for specific professional tasks.

- Management (performance) competence, which is understood as the ability to act in an organized manner by integrating part or all of the other competencies.

Production process innovation, productivity and quality directly depend on employee competence and qualification. In order to succeed in their area of expertise, people must acquire a number of competencies and qualifications, and therefore constantly update their knowledge, skills and abilities; or acquire new ones (Simonaitiene, Targamadzè 2001; Laužackas 2005; Fokienė 2007). Prahalad and Hamel (cited by Dessler 2001) claim that today's competitive advantage is determined by the ability to employ organization's special skills, or the main competence - management's ability to consolidate corporate-wide technologies and empower individual businesses to adapt quickly to changing circumstances.

Competence measurement is complicated, it requires sophisticated studies, thus, competence is often assessed on the grounds of simple, easily expressed, but often frustrated total image indicators, such as education and training (see Ledauskaite 2010). According to Stanišauskienè (2004), social competence is closely linked to ethics that raises moral questions established amongst individual and the environment and individuals involved in different relations. In order to express these notions more accurately, descriptive qualification criteria (education, professional training, experience, age) is not sufficient. These terms do not reflect the required employee qualification, thus, a term "competence" is more generally used (Čingienè et al. 2004). Lekavičienè (2001) claims that social competence, in a broad sense can be defined as an ability to cope with demands of social life, reach and maintain 
strong relationships, achieve ones goals and adapt to the environment. According to the author, socially competent person is able to influence other people. Anužienè et al. (2008) claims that elements of social competence are knowledge and skills, however, a priority is given to a person himself, who knows when, where and how to apply the present knowledge and skills. Basic social competence is defined as communication, inclusion and willingness to work across organizational boundaries. Stanišauskienè (2004) defines social competence as an ability to work with colleagues, managers, clients and create specific business climate. According to the author, socially competent person is characterized by the ability to interact, negotiate flexibly, cooperate and express ones opinion, raise clear questions. Lekavičienè (2001) claims that it is possible to distinguish three major indicators describing social competence: social skills, quality of interpersonal relations and ability to achieve goals. According to Bagdonas and Bagdonienè (2000), social competencies manifest in a wide range of ways, i.e. orientation towards unity - technology, people and organization. Skerstonienè (2006) claims that managers' social competence lies in the ability to understand complex social relationships and successfully work with other people, respect their interests. According to Malinauskas $(2006,2001)$ it is mastery and manners. Socially competent person always obeys socially acceptable standards of conduct and professional ethics, remains dignified, even when opposed to his decisions. Lekavičienè $(2001,2004)$ claims, that scientists, following diverse approaches to social competence, identify different social competence assessment indicators. Individual's social competence is one of the main factors determining his/her psychosocial adaptation. According to the author, social competence enables to distinguish those who are able to overcome the barriers of competition, adapt to changing social situations, to select without fear the most appropriate performance strategy.

Considering that changes do constantly occur in the area of Logistics, it is thus neccessary to analyse the particular features that must be attributed to people working in this area.

\section{Research on social competencies of human resources in logistics organization}

Long-term investigations (Ledauskaitè 2008, 2010; Čižiūnienè, Štaraitè 2015; Čižiūnienè et al. 2015), allowed to identify specific competencies required for employees of the logistics sector. Therefore, to conduct expert evaluation is essential. The method of expert questionnaire was selected to conduct a research on human resource competencies and social competencies in logistics organizations, as it allows collecting statistical data that reveals factual reality and its development tendencies, phenomena dependence and interaction. In order for questionnaire results to be representative, a target segment was set. Programmed answers to the questionnaire items are used with a possibility to choose an answer.

11 questionnaires were sent to the experts. 6 males and 5 females took part in the research. In accordance with the managerial experience, the highest comparative weight were constituted from 6 to 10 years, (equals to $58.3 \%$ ) and respondents having up to 3 years of managerial experience constitute $41.70 \%$ of the respondents. The size of the companies have the following distribution: number of employees (from 50 to 99) constitutes $54.55 \%$; number of employees (from 100) constitutes $27.3 \%$; number of employees from 10 to 49 constitutes $18.15 \%$.

All of the respondents indicated that appropriate personnel management strategy and policy is an important condition for business success.

Experts were asked to assess, which of the criteria are the most important in logistics organization management. Questionnaire data from eleven experts were randomly enumerated in Table 1 . In order to assess the compatibility of expert opinions, a concordance coefficient $(W)$ was calculated. Calculations showed that $W=0.4843$, and the weight of the concordance coefficient $\chi^{2} 21.3091$. $\chi^{2}$ estimated value turned out to be higher than critical $\chi_{k r}^{2}$ (equal to 9.48773) value, thus, opinion of the respondents is considered to be consistent and the average rankings indicate the general expert opinion.

Additionally, the minimum value of the concordance Wmin coefficient $(0.2156)$ was estimated, which is least than $W(0.4843)$ value, thus, expert opinions are consistent. Estimation of factors affecting logistics organization management, relevance indicators $-Q_{j}$. The obtained data are provided in Table 2 .

Table 2 provides all the factors and its distribution order from the most important to the least important. In accordance with expert assessment and conducted estimates, the successful management of logistics organizations entails the following:

- fair pay for work;

- motivation of Employee Performance Results;

- establishment of good relationships between different groups of employees; 
- owners' commitment to improve human potential in an organization;

- operational safety and social welfare.

The research aims at determining which of the competencies are relevant (according to priority) for individuals employed in respective positions:
- Head of Logistics Department perceives as relevant: Professional (specialty) competence; Management (performance) competence; Social competence.

Table 1. Rankings table of the most important criteria in logistics organization management (Source: developed by the authors)

\begin{tabular}{|c|c|c|c|c|c|}
\hline \multirow{2}{*}{ Respondent Nr. } & \multicolumn{5}{|c|}{ Factor encryption symbol $(\mathrm{m}=5) *$} \\
\hline & $\mathrm{a}$ & $\mathrm{b}$ & $\mathrm{c}$ & $\mathrm{d}$ & $\mathrm{e}$ \\
\hline E1 & 4 & 5 & 1 & 2 & 3 \\
\hline E2 & 5 & 3 & 4 & 1 & 2 \\
\hline E3 & 5 & 1 & 4 & 2 & 3 \\
\hline E4 & 4 & 2 & 3 & 1 & 5 \\
\hline E5 & 5 & 3 & 4 & 1 & 2 \\
\hline E6 & 4 & 5 & 1 & 2 & 3 \\
\hline E7 & 5 & 1 & 4 & 2 & 3 \\
\hline E8 & 5 & 1 & 4 & 2 & 3 \\
\hline E9 & 4 & 5 & 1 & 2 & 3 \\
\hline E10 & 5 & 3 & 4 & 1 & 2 \\
\hline E11 & 5 & 3 & 4 & 1 & 2 \\
\hline$\sum_{i=1}^{n} R_{i j}$ & 51 & 32 & 34 & 17 & 31 \\
\hline $\bar{R}_{j}=\frac{\sum_{i=1}^{n} R_{i j}}{n}$ & 4.636 & 2.909 & 3.091 & 1.545 & 2.818 \\
\hline$\sum_{i=1}^{n} R_{i j}-\frac{1}{2} n(m+1)$ & 18 & -1 & 1 & -16 & -2 \\
\hline$\left.\sum_{i=1}^{n} R_{i j}-\frac{1}{2} n(m+1)\right]^{2}$ & 324 & 1 & 1 & 256 & 4 \\
\hline
\end{tabular}

Note: *Criteria coding: operational safety and social welfare (a); establishment of good relationships between different groups of employees (b); owners' commitment to improve human potential in an organization; (c); fair pay for work (d); motivation of employee performance results (e).

Table 2. The most important criteria in logistics organization management (Rankings table) (Source: developed by the authors)

\begin{tabular}{c|c|c|c|c|c|c}
\hline \multirow{2}{*}{ Factor Nr. } & \multicolumn{5}{|c|}{ Factor encryption symbol } & \multirow{2}{*}{ Sum } \\
\cline { 2 - 6 } & $\mathrm{a}$ & $\mathrm{b}$ & $\mathrm{c}$ & $\mathrm{d}$ & $\mathrm{e}$ & \\
\hline $\bar{q}_{j}$ & 0.3091 & 0.1939 & 0.2061 & 0.1030 & 0.1879 & 1 \\
\hline$d_{j}$ & 0.6909 & 0.8061 & 0.7939 & 0.8970 & 0.8121 & 4 \\
\hline$Q_{j}$ & 0.1727 & 0.2015 & 0.1985 & 0.2242 & 0.2030 & 1 \\
\hline$Q_{j}^{\prime}$ & 0.0909 & 0.2061 & 0.1939 & 0.2970 & 0.2121 & 1 \\
\hline Factor distribution & 5 & 3 & 4 & 1 & 2 & \\
\hline
\end{tabular}


- Transport manager perceives as relevant: Social competence, Management (performance) competence; Professional (specialty) competence.

- Warehouse manager perceives as relevant: Social competence; Management (performance) competence; Professional (specialty) competence.

- Stockman perceives as relevant: Social competence; Management (performance) competence; Professional (specialty) competence.

- Driver perceives as relevant: Professional (specialty) competence, Management (performance) competence; Social competence.

This suggests, that competence requirements varies depending on individuals employed in different positions. On the other hand, experts were asked to assess what competencies are important for every professional working in Logistics Company: Transport manager (Tables 3-4); Warehouse manager (Tables 5-6); Driver (Tables 7-8).

In order to assess the compatibility of expert opinions, a concordance coefficient $(W)$ was calculated. Calculations showed that $W=0.2815$ and the weight of the concordance coefficient $\chi^{2} 27.8727$. $\chi^{2}$ estimated value turned out to be higher than critical $\chi_{k r}^{2}$ (equal to 16.9190) value, thus, opinion of the respondents is considered to be consistent and the average rankings indicate the general expert opinion.

Additionally, the minimum value of the concordance $W_{\min }$ coefficient $(0.1709)$ was estimated, which is least than $W(0.2815)$ value, thus, expert opinions are consistent.

Relevance indicators $-Q_{j}$ of Transport Managers' competence are estimated. Obtained data is presented in Table 4.

Table 4 provides all the factors and its distribution order from the most important to the least important. In accordance with expert assessment and conducted estimates, Transport Manager's competencies and its relevance are distributed in the following sequence:

- Communicate with co-workers, to be engaged in obtaining ones goals, willingness to work across organizational boundaries;Ability to work with colleagues, managers, clients, as well as creating of certain company's climate;

- Ability to cooperate with co-workers, express ones opinion, raise clear questions;

- Remains dignified, even when opposed to his/her decisions;
- To have a thorough understanding on Logistics services and great manners;

- Select the appropriate transport for Cargo;

- Ability to select the required technologies to implement transportation process;

- Ability to communicate with clients, negotiation flexibility;

- Ability to establish relations with potential clients and maintain the existing ones, achieve ones goals and adapt to the environment.

In order to assess the compatibility of expert opinions, a concordance coefficient $(W)$ was calculated. Calculations showed that $W=0.2381$ and the weight of the concordance coefficient $\chi^{2} 23.5686$. $\chi^{2}$ estimated value turned out to be higher than critical $\chi_{k r}^{2}$ (equal to 16.9190) value, thus, opinion of the respondents is considered to be consistent and the average rankings indicate the general expert opinion.

Additionally, the minimum value of the concordance $W_{\min }$ coefficient $(0.1709)$ was estimated, which is least than $W(0.2381)$ value, thus, expert opinions are consistent.

Relevance indicators $Q_{j}$ of Warehouse Manager competencies are estimated. Obtained data is presented in Table 6 .

Table 6 provides all the factors and its distribution order from the most important to the least important. In accordance with expert assessment and conducted estimates, Warehouse Manager's competencies and its relevance are distributed in the following sequence:

- Ability to work with colleagues, managers, clients, as well as creating of certain company's climate;

- Ability to communicate with clients, negotiation flexibility;

- Ability to cooperate with co-workers, express ones opinion, raise clear questions;

- Communicate with co-workers, to be engaged in obtaining ones goals, willingness to work across organizational boundaries;

- Ability to understand warehouse workers and respect their interests;

- To have a clear understanding on the warehouse elements and functions;

- Ability to understand and manage technological aspects of the warehouse activity;

- To have a thorough understanding on warehouse peculiarities and great manners;

- Remains dignified, even when opposed to his/her decisions;

- To have an understanding on the warehouse processes. 
Table 3. Assessment of transport manager competencies (rankings table) (Source: developed by the authors)

\begin{tabular}{|c|c|c|c|c|c|c|c|c|c|c|}
\hline \multirow{2}{*}{ Respondent Nr. } & \multicolumn{10}{|c|}{ Factor encryption symbol $(m=10)^{*}$} \\
\hline & $\mathrm{a}$ & $\mathrm{b}$ & $\mathrm{c}$ & $\mathrm{d}$ & e & $\mathrm{f}$ & g & $\mathrm{h}$ & $\mathrm{i}$ & $\mathrm{j}$ \\
\hline$E_{1}$ & 6 & 7 & 4 & 2 & 8 & 5 & 10 & 9 & 3 & 1 \\
\hline$E_{2}$ & 4 & 7 & 1 & 3 & 2 & 5 & 10 & 8 & 9 & 6 \\
\hline$E_{3}$ & 1 & 7 & 5 & 6 & 8 & 4 & 2 & 3 & 9 & 10 \\
\hline $\mathrm{E}_{4}$ & 3 & 9 & 2 & 10 & 4 & 1 & 5 & 6 & 7 & 8 \\
\hline $\mathrm{E}_{5}$ & 6 & 7 & 4 & 2 & 8 & 5 & 10 & 9 & 3 & 1 \\
\hline $\mathrm{E}_{6}$ & 6 & 7 & 4 & 2 & 8 & 5 & 10 & 9 & 3 & 1 \\
\hline $\mathrm{E}_{7}$ & 1 & 6 & 2 & 7 & 8 & 3 & 4 & 5 & 9 & 10 \\
\hline $\mathrm{E}_{8}$ & 1 & 6 & 2 & 7 & 8 & 3 & 4 & 5 & 9 & 10 \\
\hline $\mathrm{E}_{9}$ & 6 & 7 & 4 & 2 & 8 & 5 & 10 & 9 & 3 & 1 \\
\hline $\mathrm{E}_{10}$ & 1 & 6 & 2 & 7 & 8 & 3 & 4 & 5 & 9 & 10 \\
\hline$E_{11}$ & 1 & 4 & 3 & 10 & 8 & 2 & 9 & 6 & 7 & 5 \\
\hline$\sum_{i=1}^{n} R_{i j}$ & 36 & 73 & 33 & 58 & 78 & 41 & 78 & 74 & 71 & 63 \\
\hline $\bar{R}_{j}=\frac{\sum_{i=1}^{n} R_{i j}}{n}$ & 3.273 & 6.636 & 3.000 & 5.273 & 7.091 & 3.727 & 7.091 & 6.727 & 6.455 & 5.727 \\
\hline$\sum_{i=1}^{n} R_{i j}-\frac{1}{2} n(m+1)$ & -24.5 & 12.5 & -27.5 & -2.5 & 17.5 & -19.5 & 17.5 & 13.5 & 10.5 & 2.5 \\
\hline$\left[\sum_{i=1}^{n} R_{i j}-\frac{1}{2} n(m+1)\right]^{2}$ & 600.25 & 156.25 & 756.25 & 6.25 & 306.25 & 380.25 & 306.25 & 182.25 & 110.25 & 6.25 \\
\hline
\end{tabular}

Note: *Criteria coding: ability to determine the possibilities of different modes of transport in the process of cargo transportation; (a); ability to establish relations with potential clients and maintain the existing ones, achieve ones goals and adapt to the environment; (b); communicate with co-workers, to be engaged in obtaining ones goals, willingness to work across organizational boundaries (c); ability to work with colleagues, managers, clients, as well as creating of certain company's climate (d); ability to communicate with clients, negotiation flexibility (e); ability to cooperate with co-workers, express ones opinion, raise clear questions (f); ability to select the required technologies to implement transportation process; $(\mathrm{g})$; select the appropriate transport for cargo $(\mathrm{h})$; to have a thorough understanding on Logistics services and great manners; (i); remains dignified, even when opposed to his/her decisions (j).

Table 4. Assessment of transport manager competencies (rankings table) (Source: developed by the authors)

\begin{tabular}{c|c|c|c|c|c|c|c|c|c|c|c}
\hline \multirow{2}{*}{$\begin{array}{c}\text { Indicator } \\
\text { mark }\end{array}$} & \multicolumn{10}{c}{ Factor encryption symbol } & \multirow{2}{*}{ Sum } \\
\cline { 2 - 12 } & $\mathrm{a}$ & $\mathrm{b}$ & $\mathrm{c}$ & $\mathrm{d}$ & $\mathrm{e}$ & $\mathrm{f}$ & $\mathrm{g}$ & $\mathrm{h}$ & $\mathrm{i}$ & $\mathrm{j}$ & \\
\hline $\bar{q}_{j}$ & 0.0595 & 0.1207 & 0.0545 & 0.0959 & 0.1289 & 0.0678 & 0.1289 & 0.1223 & 0.1174 & 0.1041 & 1 \\
\hline$d_{j}$ & 0.9405 & 0.8793 & 0.9455 & 0.9041 & 0.8711 & 0.9322 & 0.8711 & 0.8777 & 0.8826 & 0.8959 & 9 \\
\hline$Q_{j}$ & 0.1045 & 0.0977 & 0.1051 & 0.1005 & 0.0968 & 0.1036 & 0.0968 & 0.0975 & 0.0981 & 0.0995 & 1 \\
\hline$Q_{j}^{\prime}$ & 0.1405 & 0.0793 & 0.1455 & 0.1041 & 0.0711 & 0.1322 & 0.0711 & 0.0777 & 0.0826 & 0.0959 & 1 \\
\hline $\begin{array}{c}\text { Factor } \\
\text { encryption } \\
\text { symbol }\end{array}$ & 2 & 7 & 1 & 3 & 10 & 4 & 9 & 8 & 6 & 5 & \\
\hline
\end{tabular}


Table 5. Assessment of warehouse manager competencies (ranking table) (Source: developed by the authors)

\begin{tabular}{|c|c|c|c|c|c|c|c|c|c|c|}
\hline \multirow{2}{*}{ Respondent $\mathrm{Nr}$} & \multicolumn{10}{|c|}{ Factor encryption symbol $(m=10)^{*}$} \\
\hline & $\mathrm{a}$ & $\mathrm{b}$ & $\mathrm{c}$ & $\mathrm{d}$ & e & $\mathrm{f}$ & $\mathrm{g}$ & $\mathrm{h}$ & $\mathrm{i}$ & $\mathrm{j}$ \\
\hline $\mathrm{E}_{1}$ & 10 & 9 & 8 & 5 & 1 & 2 & 6 & 3 & 4 & 7 \\
\hline $\mathrm{E}_{2}$ & 3 & 4 & 1 & 6 & 2 & 5 & 7 & 8 & 9 & 10 \\
\hline$E_{3}$ & 10 & 3 & 2 & 1 & 9 & 8 & 7 & 6 & 5 & 4 \\
\hline $\mathrm{E}_{4}$ & 10 & 1 & 9 & 5 & 4 & 3 & 8 & 2 & 6 & 7 \\
\hline $\mathrm{E}_{5}$ & 10 & 9 & 8 & 5 & 1 & 2 & 6 & 3 & 4 & 7 \\
\hline $\mathrm{E}_{6}$ & 10 & 9 & 8 & 5 & 1 & 2 & 6 & 3 & 4 & 7 \\
\hline $\mathrm{E}_{7}$ & 6 & 7 & 1 & 2 & 8 & 3 & 9 & 10 & 5 & 4 \\
\hline $\mathrm{E}_{8}$ & 5 & 6 & 1 & 2 & 7 & 8 & 3 & 4 & 9 & 10 \\
\hline $\mathrm{E}_{9}$ & 10 & 9 & 8 & 5 & 1 & 2 & 6 & 3 & 4 & 7 \\
\hline$E_{10}$ & 5 & 6 & 1 & 2 & 7 & 8 & 3 & 4 & 9 & 10 \\
\hline$E_{11}$ & 10 & 2 & 3 & 1 & 4 & 5 & 6 & 7 & 9 & 8 \\
\hline$\sum_{i=1}^{n} R_{i j}$ & 89 & 65 & 50 & 39 & 45 & 48 & 67 & 53 & 68 & 81 \\
\hline $\bar{R}_{j}=\frac{\sum_{i=1}^{n} R_{i j}}{n}$ & 8.091 & 5.909 & 4.545 & 3.545 & 4.091 & 4.364 & 6.091 & 4.818 & 6.182 & 7.364 \\
\hline$\sum_{i=1}^{n} R_{i j}-\frac{1}{2} n(m+1)$ & 28.5 & 4.5 & -10.5 & -21.5 & -15.5 & -12.5 & 6.5 & -7.5 & 7.5 & 20.5 \\
\hline$\left.\sum_{i=1}^{n} R_{i j}-\frac{1}{2} n(m+1)\right]$ & 812.25 & 20.25 & 110.25 & 462.25 & 240.25 & 156.25 & 42.25 & 56.25 & 56.25 & 420.25 \\
\hline
\end{tabular}

Note: ${ }^{*}$ Criteria coding: to have an understanding on the warehouse processes; (a); to have a clear understanding on the warehouse elements and functions; (b); communicate with co-workers, to be engaged in obtaining ones goals, willingness to work across organizational boundaries; (c); ability to work with colleagues, managers, clients, as well as creating of certain company's climate (d); ability to communicate with clients, negotiation flexibility (e); ability to cooperate with co-workers, express ones opinion, raise clear questions (f); ability to understand and manage technological aspects of the warehouse activity (g); ability to understand warehouse workers and respect their interests; (h); to have a thorough understanding on warehouse peculiarities and great manners (i); remains dignified, even when opposed to his/her decisions (j).

Table 6. Assessment of warehouse manager competencies (ranking table) (Source: developed by the authors)

\begin{tabular}{|c|c|c|c|c|c|c|c|c|c|c|c|}
\hline \multirow{2}{*}{$\begin{array}{c}\text { Indicator } \\
\text { mark }\end{array}$} & \multicolumn{10}{|c|}{ Factor encryption symbol } & \multirow{2}{*}{ Sum } \\
\hline & $\mathrm{a}$ & $\mathrm{b}$ & $\mathrm{c}$ & $\mathrm{d}$ & $\mathrm{e}$ & $\mathrm{f}$ & $\mathrm{g}$ & $\mathrm{h}$ & $\mathrm{i}$ & $\mathrm{j}$ & \\
\hline $\bar{q}_{j}$ & 0.1471 & 0.1074 & 0.0826 & 0.0645 & 0.0744 & 0.0793 & 0.1107 & 0.0876 & 0.1124 & 0.1339 & 1 \\
\hline$d_{j}$ & 0.8529 & 0.8926 & 0.9174 & 0.9355 & 0.9256 & 0.9207 & 0.8893 & 0.9124 & 0.8876 & 0.8661 & 9 \\
\hline$Q_{j}$ & 0.0948 & 0.0992 & 0.1019 & 0.1039 & 0.1028 & 0.1023 & 0.0988 & 0.1014 & 0.0986 & 0.0962 & 1 \\
\hline$Q_{j}^{\prime}$ & 0.0529 & 0.0926 & 0.1174 & 0.1355 & 0.1256 & 0.1207 & 0.0893 & 0.1124 & 0.0876 & 0.0661 & 1 \\
\hline $\begin{array}{c}\text { Factor } \\
\text { encryption } \\
\text { symbol }\end{array}$ & 10 & 6 & 4 & 1 & 2 & 3 & 7 & 5 & 8 & 9 & \\
\hline
\end{tabular}


Table 7. Ranking table of the obtained assessment driver (Source: developed by the authors)

\begin{tabular}{|c|c|c|c|c|c|c|c|c|c|c|}
\hline \multirow{2}{*}{ Respondent Nr. } & \multicolumn{10}{|c|}{ Factor encryption symbol $(m=10)^{*}$} \\
\hline & $\mathrm{a}$ & $\mathrm{b}$ & $\mathrm{c}$ & $\mathrm{d}$ & $\mathrm{e}$ & $\mathrm{f}$ & g & $\mathrm{h}$ & $\mathrm{i}$ & $\mathrm{j}$ \\
\hline$E_{1}$ & 3 & 2 & 6 & 5 & 4 & 9 & 8 & 7 & 10 & 1 \\
\hline $\mathrm{E}_{2}$ & 8 & 9 & 1 & 2 & 5 & 4 & 3 & 6 & 7 & 8 \\
\hline$E_{3}$ & 10 & 2 & 7 & 8 & 6 & 5 & 9 & 1 & 4 & 3 \\
\hline $\mathrm{E}_{4}$ & 8 & 7 & 9 & 5 & 4 & 3 & 10 & 2 & 6 & 7 \\
\hline $\mathrm{E}_{5}$ & 10 & 9 & 8 & 5 & 1 & 2 & 6 & 3 & 4 & 7 \\
\hline $\mathrm{E}_{6}$ & 3 & 2 & 6 & 5 & 4 & 9 & 8 & 7 & 10 & 1 \\
\hline $\mathrm{E}_{7}$ & 4 & 1 & 3 & 2 & 5 & 6 & 8 & 9 & 10 & 7 \\
\hline $\mathrm{E}_{8}$ & 7 & 1 & 2 & 3 & 5 & 8 & 9 & 10 & 6 & 4 \\
\hline $\mathrm{E}_{9}$ & 7 & 1 & 2 & 3 & 5 & 8 & 9 & 10 & 6 & 4 \\
\hline $\mathrm{E}_{10}$ & 8 & 7 & 9 & 5 & 4 & 3 & 10 & 2 & 6 & 7 \\
\hline$E_{11}$ & 4 & 1 & 2 & 3 & 5 & 6 & 7 & 8 & 10 & 9 \\
\hline$\sum_{i=1}^{n} R_{i j}$ & 72 & 42 & 55 & 46 & 48 & 63 & 87 & 65 & 79 & 58 \\
\hline$\overline{-}_{j}=\frac{\sum_{i=1}^{n} R_{i j}}{n}$ & 6.545 & 3.818 & 5.000 & 4.182 & 4.364 & 5.727 & 7.909 & 5.909 & 7.182 & 5.273 \\
\hline$\sum_{i=1}^{n} R_{i j}-\frac{1}{2} n(m+1)$ & 11.5 & -18.5 & -5.5 & -14.5 & -12.5 & 2.5 & 26.5 & 4.5 & 18.5 & -2.5 \\
\hline$\sum_{i=1}^{n} R_{i j}-\frac{1}{2} n(m+1)$ & 132.25 & 342.25 & 30.25 & 210.25 & 156.25 & 6.25 & 702.25 & 20.25 & 342.25 & 6.25 \\
\hline
\end{tabular}

Note: ${ }^{*}$ Criteria coding: constantly improve their professional competence (a); identify and eliminate simple faults in the car and trailers; (b); possession of the Code 95 (Drivers Qualification Card) (c); ability to work with colleagues and managers (d); ability to use information and communication means, road maps (e); to know the requirements applicable to international road transport (f); thorough understanding of the vehicle control design, operations and technical requirements for traffic safety $(\mathrm{g})$; to know complementary car devices for proper microclimate setup in the cabin, its impact on traffic safety and driver's health; (h); follow the guidelines of the work and rest requirements; (i); ability to operate trailers under extreme conditions (j).

Table 8. Ranking table of the obtained assessment driver (Source: developed by the authors)

\begin{tabular}{c|c|c|c|c|c|c|c|c|c|c|c}
\hline $\begin{array}{c}\text { Indicator } \\
\text { mark }\end{array}$ & \multicolumn{9}{c|}{ Factor encryption symbol } & Sum \\
\hline & $\mathrm{a}$ & $\mathrm{b}$ & $\mathrm{c}$ & $\mathrm{d}$ & $\mathrm{e}$ & $\mathrm{f}$ & $\mathrm{g}$ & $\mathrm{h}$ & $\mathrm{i}$ & $\mathrm{j}$ & \\
\hline $\bar{q}_{j}$ & 0.1171 & 0.0683 & 0.0894 & 0.0748 & 0.0780 & 0.1024 & 0.1415 & 0.1057 & 0.1285 & 0.0943 & 1 \\
\hline$d_{j}$ & 0.8829 & 0.9317 & 0.9106 & 0.9252 & 0.9220 & 0.8976 & 0.8585 & 0.8943 & 0.8715 & 0.9057 & 9 \\
\hline$Q_{j}$ & 0.0981 & 0.1035 & 0.1012 & 0.1028 & 0.1024 & 0.0997 & 0.0954 & 0.0994 & 0.0968 & 0.1006 & 1 \\
\hline$Q_{j}^{\prime}$ & 0.0797 & 0.1285 & 0.1073 & 0.1220 & 0.1187 & 0.0943 & 0.0553 & 0.0911 & 0.0683 & 0.1024 & 1 \\
\hline $\begin{array}{c}\text { Factor encryp- } \\
\text { tion symbol }\end{array}$ & 8 & 1 & 4 & 2 & 3 & 6 & 10 & 7 & 9 & 5 & \\
\hline
\end{tabular}


In order to assess the compatibility of expert opinions, a concordance coefficient $(W)$ was calculated. Calculations showed that $W=0.1952$ and the weight of the concordance coefficient $\chi^{2} 19.3240$. $\chi^{2}$ estimated value turned out to be higher than critical $\chi_{k r}^{2}$ (equal to 16.9190 ) value, thus, opinion of the respondents is considered to be consistent and the average rankings indicate the general expert opinion.

Additionally, the minimum value of the concordance $W_{\min }$ coefficient $(0.1709)$ was estimated, which is least than $W(0.1952)$ value, thus, expert opinions are consistent.

Relevance indicators $Q_{j}$ of the Driver's competence are estimated. Obtained data is presented in Table 8.

Table 8 provides all the factors and its distribution order from the most important to the least important. In accordance with expert assessment and conducted estimates, Driver's competencies and its relevance are distributed in the following sequence:

- Identify and eliminate simple faults in the car and trailers;

- Ability to work with colleagues and managers;

- Ability to use information and communication means, road maps;

- Possession of the Code 95 (Drivers Qualification Card);

- Ability to operate trailers under extreme conditions;

- To know the requirements applicable to international road transport;

- To know complementary car devices for proper microclimate setup in the cabin, its impact on traffic safety and driver's health;

- Constantly improve their professional competence;

- Follow the guidelines of the work and rest requirements;

- Thorough understanding of the vehicle control design, operations and technical requirements for traffic safety.

In accordance with research and expert assessment, the Competencies of the Head of Logistics Department and its relevance are distributed in the following sequence:

- To know materials management functions;

- to have a thorough understanding on establishment and operation peculiarities of the logistics supply chain;

- Ability to communicate, negotiation flexibility;
- Remains dignified, even when opposed to his/her decisions;

- To communicate with subordinates and involve them into pursuance of organization's goals as soon as possible;

- to have a thorough understanding and great manners;

- Ability to work with colleagues, managers, clients, as well as creating of certain company's climate;

- Ability to establish relations with potential clients and maintain the existing ones, achieve sales objectives and adapt to the environment;

- Ability to lead and manage human resources and motivate employees of logistics organization;

- Ability to assess development opportunities of transport/logistics business in international market.

Moreover, the research have shown that the majority of the respondents $(89.51 \%)$ assume, that in the future attention must be given to abilities to prepare business development strategy and $10.49 \%$ of the respondents consider, that the ability to establish product/service sales strategies will be highly appreciated. Therefore, the competencies of highly qualified employees should be developed.

\section{Conclusions}

Human resources create value for organization when they are used and efficiently managed in conjunction with other resources, which emphasizes the importance of human resource management system.

All of the respondents indicated that appropriate personnel management strategy and policy is an important condition for business success, which indicates that human resource competencies are relevant in logistics organization management.

The research results have shown that social competence is important for persons, working directly with clients and their orders, professional and social competencies are important for managerial work, while profession-oriented competencies are substantial for technical workers.

\section{References}

Armstrong, M. 1999. The reward and benefits audit. Cambridge: Cambridge Strategy Publications Ltd.

Anužienè, B.; Andriekiené, R. M.; Jatkauskas, E.; Zubrickiené, I. 2008. Andragogikos technologijos: nuo koncepcijos kūrimo iki jos igyvendinimo 
[Technology of Andragogy: from concept development to implementation]. Klaipeda: Klaipédos universiteto leidykla (in Lithuanian).

Bagdonas, E.; Bagdoniene, L. 2000. Administravimo principai [Principles of administration]. Kaunas: Technologija (in Lithuanian).

Barysienė, J.; Batarlienè, N.; Bazaras, D.; Čižiūnienè, K.; Griškevičienè, D.; Griškevičius, A. J.; Lazauskas, J.; Mačiulis, A.; Palšaitis, R.; Vasilis Vasiliauskas, A.; Vasilienè-Vasiliauskienè, V. 2015. Analysis of the current logistics and transport challenges in the context of the changing environment, Transport 30(2): 233-241.

http://dx.doi.org/10.3846/16484142.2015.1046403

Becker, G. 2008. Investments in human capital: effects on earnings. Human capital. New York: Columbia University Press for NBER.

Čingienè, V.; Laskienè, S.; Kavaliauskas, S. 2004. Sportas kaip laisvalaikis, profesija ir verslas ES kontekste [Sport as a leisure, profession and business in the context of the EU], iš ES - 2004: iššükiai, procesai ir Europos studijos. Tarptautines mokslinès konferencijos pranešimu medžiaga. I knyga. Kaunas: LKKA (in Lithuanian).

Čižiūnienè, K.; Vaičiūtè, K.; Batarlienè, N. 2015. Research on competencies of human resources in transport sector: Lithuanian case study, Procedia Engineering 134: 336-343 [online], [cited 22 January 2016]. Available from Internet:

http://www.sciencedirect.com/science/journal/ 18777058

Čižiūnienè, K.; Štaraitè, E. 2015. Absolventų integracija i darbo rinką ir tęstinio mokymosi, kaip investicijų i žmogiškaji kapitala, poreikis [Integration of graduates into the labor market and demand for continuing education as an investment in human capital], iš Respublikinès mokslinès-praktinès konferencijos: Studijos kintančioje verslo aplinkoje, konferencijos, ìvykusios Alytaus kolegijoje $2015 \mathrm{~m}$. balandžio mèn. $24 \mathrm{~d}$. pranešimų medžiaga, 111-115 (in Lithuanian).

Dessler, G. 2001. Personalo valdymo pagrindai [Basics of personnel management]. Kaunas: Poligrafija ir informatika (in Lithuanian).

Fokienè, A. 2007. Neformaliojo ir savaiminio mokymosi pasiekimų vertinimas profesijos mokytojų rengime: poreikiai ir prielaidos II [Evaluation of Non-formal and informal learning achievements in vocational teacher training: demands and assumptions II], Profesinis rengimas, tyrimai ir realijos 14: 36-50 (in Lithuanian).

Fitzroy, P.; Hubbert, J. 2005. Strategic management: creating value in a turbulent world. New York: John Wiley and Sons.

Laužackas, R. 2005. Profesinio rengimo metodologija: monografija [Methodology of vocational training: Monograph]. Kaunas: Vytauto Didžiojo universiteto leidykla (in Lithuanian).
Ledauskaitè, K. 2010. Transporto sektoriaus žmogiškuju ištekliu potencialo ekonominis vertinimas: disertacija [Economic assessment of human resource potential in transport sector: thesis]. Vilnius: Technika (in Lithuanian).

Ledauskaite, K. 2008. Evaluation of Lithuania and Estonia transport management specialists competitiveness possibility, Jelenkori társadalmi és gazdasági folyamatok 3(1): 116-122.

Ledauskaite, K.; Bazaras, D. 2008. Actual attitudes of demands for specialists in transport sector, Transport and Telecommunication 9(1): 29-33.

Lekavičienè, R. 2001 Socialinès kompetencijos kriterijai ir vertinimas. Lietuvos studentu tyrimas [Criteria and Evaluation of Social Competencies. Investigation conducted by Lithuanian students]. Kaunas: VDU (in Lithuanian).

Lekavičienè, R. 2004. Socialinès kompetencijos kriterijų problema: studentų socialinių igūdžių ir socialinio prioriteto santykio tyrimas [Problem of social competence criteria: survey of students' social skills and social priority ratio], Ugdymas. Kūno kultūra. Sportas 1(51): 30-36 (in Lithuanian).

Leonienè, B. 2001. Darbuotoju vadyba [Employee Management]. Kaunas: Šviesa (in Lithuanian).

Lietuvos Respublikos Seimas. 2004. Lietuvos Respublikos Śvietimo istatymas [The Law of the Republic of Lithuania on Education] [online], [cited 22 January 2016]. Available from Internet: http://www3.lrs.lt/pls/inter3/dokpaieska.showdoc 1 ? p_id $=238646 \& p \_q u e r y=6 . \% 20$ Kompetencija $\% 20 \%$ 96\%20mok\%EBjimas\%20atlikti\%20tam $\% 20$ tikr\% E0\%20veikl\%E0\%2C\%20remiantis\%20\%E1gyt \%F $8 \% 20 \%$ FEini $\%$ F8 $\% 2$ C $\% 20 \%$ E1g\%FBd $\%$ FEi $\%$ F8 $\% 2 \mathrm{C} \% 20$ geb $\%$ EBjim $\% \mathrm{~F} 8 \% 2 \mathrm{C} \% 20$ vertybini $\% \mathrm{~F} 8 \%$ 20nuostat $\% F 8 \% 20$ visuma.\&p_tr2=2buotojus (in Lithuanian).

Malinauskas, R. 2006. Sporto pedagogu ir sportininku socialinio psichologinio rengimo ypatumai [Social psychological training peculiarities of sports teachers and athletes]. Vilnius: Lietuvos sporto informacijos centras (in Lithuanian).

Malinauskas, R. 2001. Pedagogikos studentu parengtis pedagoginèms funkcijoms atlikti [Students' Readiness to perform pedagogical functions], Pedagogika 48: 22-32 (in Lithuanian).

Prentkovskis, O.; Kliukas, R.; Vasiliauskas, A. V.; Daniūnas, A.; Marina, V.; Ledauskaitè, K.; Zemlickienè, V. 2009. Transport management: the popularity of study programmes among the applicants to lithuanian universities evaluating the qualifications of graduates in the labour-market, Transport 24(2): 154-169.

http://dx.doi.org/10.3846/1648-4142.2009.24.154-169

Priem, R. L.; Cycyota, C. S. 2001. On strategic judgment, in M. A. Hitt, R. E. Freeman, J. R. Harrison. 2006. Handbook of strategic management. Oxford: Blackwell Publishing. 
Simonaitienè, B.; Targamadzè, V. 2001. Mokytoju profesinè kompetencija: jos plètotès darbo vietoje galimybiu tyrimas, II [Teacher occupational competences: feasibility study on its development in the workplace II], Socialiniai mokslai 3(29): 33-41 (in Lithuanian).

Skerstonienè, A. 2006. Socialinès kompetencijos aspektai rengiant turizmo ir viešbučiu administravimo specialistus Vilniaus kolegijoje. Rengiamo specialisto atitikmuo rinkos poreikiams [Aspects of Social Competencies in preparation of Tourism and Hotel Administration specialists in Vilnius College. Compliance of the trained specialists with market demands]. Vilnius: Vilniaus kolegija (in Lithuanian).

Stanišauskienè, V. 2004. Rengimosi karjerai proceso socioedukologiniai pagrindai [Socio-educational fundamentals of Career preparation process]. Kaunas: Technologija (in Lithuanian).
Stukaite, D. 2000. Kvalifikacija darbo vietų vertinimo požiūriu [Qualification from the perspective of occupational assessment], iš Ekonomika ir vadyba2000. Aktualijos ir metodologija. Tarptautinès konferencijos pranešimu medžiaga. Kaunas: Technologija, 432-433 (in Lithuanian).

Underis, V. 2015. Tinkama personalo valdymo strategija ir politika - svarbi verslo sèkmès salyga [Appropriate personnel management strategy and policy - an important condition for business success] [online], [cited 3 February 2016]. Available from Internet: http://www.trainings.lt/?pid=7\&id=11 (in Lithuanian). 